\title{
Global economic planning as a challenge for the labour movement
}

\author{
Jörg Nowak* \\ https://orcid.org/0000-0002-3213-4252
}

\begin{abstract}
The veil is not removed from the countenance of the social life process until it becomes production by freely associated men, and stands under their conscious and planned control. Marx, 1992, p. 173.
\end{abstract}

Recent special issues on economic planning in the academic journals Actuel Marx (2019) and South Atlantic Quarterly (2020) document a renewed interest in the topic, while the global pandemic and the climate crisis demonstrate the actual necessity of global economic planning. This contribution aims to lay out why the labour movement can have a special impact on the debate and practice on planning, and why economic planning should concern the labour movement. It is not only that the labour movement consists of large organised groups within the economy that are able to initiate and implement wider economic changes. Many of the demands and goals of the labour movement cannot be tackled without any recourse to economic planning. On the other hand, economic planning is largely absent from debates around the labour movement or in academic studies on labour.

The central line of argument in this contribution is that the urgency of the economic, social and environmental crises demands to go beyond the efforts of global trade unions to install more Global Framework Agreements or Decent Work 
Campaigns that often only come with piecemeal changes, if at all. The urgency of the current crisis also demands to go beyond green innovation in the sense of higher resource efficiency of product lines or sectors since $\mathrm{CO}_{2}$ emissions are increasing on a global level (OECD, 2018). In other words, ecological planning across sectors and continents is on the agenda. The social uprisings in various countries around the globe that erupted in 2019 and 2020 demonstrate the emerging pressure from below towards a broader vision of systemic change.

The shift of emphasis towards Global Economic Planning opens up the following perspectives: 1 . It allows to study and adapt the methods used by transnational corporations in economic planning for alternative purposes. 2. It allows to retrieve experiences made both in capitalist state planning, i.e. in the framework of industrial policy and developmental states, and in socialist state planning and to apply enhanced versions of both. 3. It allows to intervene strategically in order to exploit the potentials of renewable energy for which investment is stagnating globally since 2015. 4. It offers an avenue for the labour movement to become a reliable partner of environmental initiatives and the global climate movement. 5. It can provide an avenue for mass participation in systemic change with concrete objectives like the conversion of the automobile industry, decentralised renewable energy grids, and public and community based health and care systems.

The proponents of liberal capitalism usually deny that any planning occurs in capitalism since capitalism is allegedly based on a free market where individual entrepreneurs take decisions guided by price signals. But actually plenty of planning is going on within capitalism, but mostly according to the interests of multinational and national capital. For example, there are strategic subsidies and tax breaks by states for a number of economic sectors across the world, and energy and water provision is often planned along with investment in large industrial projects. Plus, spending in defense, security and surveillance infrastructure usually includes some form of state planning, including huge budgets and often very damaging environmental impact (Belcher et al., 2020). More recently, some aspects of planning are debated again under the term industrial policy (Rodrik, 2004; Mazzucato, 2018).

Around 25 per cent of global trade takes place within multinational companies. While those companies engage in coordination among themselves only to a limited extent, they administer their internal financial and product flows, purchases and personnel policies on a global level. This demonstrates the possibility of global planning, as it is practiced inside capitalist enterprises, including illicit or doubtful practices like the use of tax havens, transfer pricing and other means to minimise taxation by using differences between tax regimes and concealing the market value of produced goods or of services (Shaxson, 2021). The global pandemic caused by 
the proliferation of the virus that causes Covid-19 demonstrates that these global economic networks are not organised in a manner that benefits the general population. Despite of enormously advanced means of production and highly developed technologies, national orientations of governments, patent regimes and profit interests prevented the availability of vaccines, protective gear, medical equipment, drugs and other urgently needed products.

Historically, the most advanced forms of capitalist planning served as a blueprint for socialist models of planning. The Soviet Union adapted the systems of planning used in large capitalist enterprises in the 1920s and developed them in their own way, largely based on planning in one workplace or enterprise unit. When Cuba introduced economic planning in the 1960s, the country's government used methods that were used in multinational companies during this period, based on planning across enterprise units, while the Soviet Union stuck to the methods of the 1920 to a large extent. These differences in planning in Cuba and the Soviet Union led to a then famous debate between planners from both countries (Dupuy \& Irchik 1978; Roca, 1986; Zimbalist, 1987).

It is in the same way that socialist economic planning can evaluate and adapt parts of capitalist planning today. The ideological challenges consist in the fact that many social movements and progressive institutions today focus on piecemeal changes, and especially the labour movement at the level of global union federations develops an increasing focus on agreements with multinational corporations as instruments of labour regulation. In contrast to this stands the global environmental movement which is asking for rapid, urgent and fundamental change, as well as the wave of popular uprisings that is rocking the globe since 2019 in Algeria, Sudan, Haiti, Chile, Ecuador, Thailand, Belarus, Iraq, Iran, Lebanon and many other countries. The urgency of the global environmental and health crisis, and the enormous economic restructuring during and in the wake of the Covid-19 crisis with massive losses of jobs, social security and income for the global working class present an opportunity for the global labour movement to re-enter into the scene with a broad agenda, which can turn it into an attractive partner for other progressive movements. The debate around "essential work" during the early phase of the Covid-19 crisis shone light on the fact which parts of the economy are of special importance for the vast majority of the population and that exactly those essential workers are usually underpaid and work under conditions that lead to sickness and bodily strain (Cook et al., 2020). Both the problems faced by national health systems during the pandemic, and the fact that the climate crisis got out of hand demonstrate that another type of planning with different priorities is necessary in order to reduce emissions and protect the health of populations. Voluntary obligations of governments that were agreed 
upon at the Paris climate summit in December 2015 to restrict global warming to 1.5 degrees Celsius did not work until now, since emissions keep growing (IPCC, 2018).

The main challenge at this point is to break the ideological deadlock of a focus on so-called market solutions which are today the actual existing forms of planning, guided by international organisations, financial institutions and corporate headquarters (Hudson, 2021). A focus on alternative global economic planning as something that can be exercised by trade unions and social movements can have the effect of establishing a new reference point for social movements and progressive politics in a period of profound social crisis. Apart from the urgency to address poverty, ecological collapse and the general social crisis caused by the pandemic, such initiatives in favour of global economic planning would open a new page and present the labour movement as a force to be reckoned with.

In the following, I will outline why global economic planning is an urgent agenda for the labour movement today, in a post-Covid-19 and post-climate change conjuncture. In a first part, I will demonstrate why economic planning is key for a response to the current post Covid-19 wave of corporate restructuring that comes with millions of job losses around the globe. Second, I will outline why ecological responses to the climate crisis require global economic planning. In a third part, I will highlight challenges and unresolved problems regarding economic planning and which historical debates and experiences mark signposts for future avenues into economic planning.

\section{Planning and post-Covid-19 corporate restructuring}

The outbreak of the Covid-19 pandemic has led to an unprecedented wave of dismissals and job losses, exemplified by large companies shedding thousands of jobs. The airline industry was especially affected, with Boeing shedding 12.000, Airbus 15.000 and Lufthansa 39.000 jobs since March 2020. But also the automobile industry, in transition to the production of electric cars which need less labour power, was hit: Nissan cut 20.000 jobs, Renault 15.000 and tire company Continental 30.000 jobs since the outbreak of the pandemic. But also German Commerzbank announced a cut of 10.000 jobs in early 2021 (all numbers from the European Restructuring Monitor).

These numbers just give a first impression what labour markets around the world are facing, with enormous salary losses, which are much more pronounced in developing countries, and considerable inflation of food prices on various continents. In 2020, 8.8 per cent of global working hours were lost, equivalent to 255 million full-time jobs, resulting in a labour income loss of 4.4 per cent relative to 2019, before income support (ILO, 2021). This income loss was strongest in the Americas with 
10.3 per cent, and lowest in Asia and the Pacific with 6.6 per cent (ILO, 2021, p. 15). In the Us, loss in income after benefits, was on average 9 per cent; in the UK, 3 per cent; in Brazil, 21 per cent, and in Peru, 56 per cent. Total global employment decline in 2020 has been estimated in January 2021 at 114 million relative to 2019, and about 60 million for 2021 (ILO, 2021, p. 12).

These developments will lead to an increase in class confrontation, and once the pandemic is over, we can expect a surge in labour protests around the world. Various scholars agree that there will be no post-Covid-19 normalisation after the pandemic due to the profound economic and social effects of the pandemic and the measures taken to contain it. For Canada and the Us, early estimates show that a third of workers have lost half of their income, and in the UK 25 per cent and in China 45 per cent of workers report a similar loss of income (Bell \& Blanchflower, 2020). In India alone, 170 million workers have lost their job due to the lockdowns imposed in March and June 2021 (Singhi \& Tagat, 2020; Miyamura, 2021). These job losses affect primarily workers in the private service sector, and in some areas of production, while office workers are much less affected. Thus, there is much polarisation within the working class in terms of the effects of the pandemic-induced economic crisis.

But polarization between groups of companies is increasing, too. Michael Roberts hints at the fact that total corporate profits have dropped $30 \%$ since the beginning of the pandemic (2021). Thus, while Big Tech made higher profits than before the pandemic, this is not the general picture. The concentration of wealth has increased enormously during the pandemic, which implies that some players are losing out. The phenomenon of zombie companies who are unable to pay their debt has become endemic:

[...] according to Bloomberg, in the US, almost 200 big corporations have joined the ranks of so-called "zombie' firms since the onset of the pandemic. They now account for $20 \%$ of the top 3000 largest publicly-traded companies, with debts of $\$ 1.36$ trillion. That means 527 of the 3000 companies didn't earn enough to meet their interest payments! (Roberts, 2021).

If this corporate debt pile cannot be dealt with in some way, a new banking crisis is at the horizon. In other words, workers are facing a new world of more insecurity, rising prices, falling wages, and probably a wave of bankruptcies of some of those zombie companies. Many of the changes in corporate restructuring might have been in the drawers of managers already, ready to be launched during the next crisis, or might have been propelled by digitalisation anyway. The Covid-19 pandemic accelerated those processes, increasing the reserve army of labour, but also affects other sectors like the airline industry, tourism, cinemas and the hospitality sector 
in addition, as a direct consequence of the pandemic. Thus, for the world of labour the pandemic presents the perfect recipe for disaster.

The labour movement which has seen a timid revival in the past ten years or so, without yet gaining enough ground in order to consolidate the achievements made, is facing a struggle of life and death with the consequences of the Covid-19 pandemic. Such a challenge can also provide a chance to prove itself as an actor that is able to adapt and respond to unexpected circumstances.

The first measures of global planning to confront the adverse effect of the pandemic on labour would consist in massive government investment in the public health, care, transport and education sectors, creating jobs and incomes, future perspectives, and recreating a public infrastructure that has seen much cuts and retrenchment in the past years or has never existed in a comprehensive manner in many countries. A much greater amount of social labour will have to be devoted to care work in order to fulfil unmet needs and to socialise labour which is to a large extent provided as unpaid labour by women. At the same time, it would be necessary increase taxation of large corporations and rich individuals, fight tax evasion, and to nationalise private banks in order to finance the comprehensive public sector.

A comprehensive public sector can only be one element of such a strategy. A second element would be to implement sweeping changes in private workplaces. Existing workplaces will be divided between all workers via a shortening of the working time to 30 hours a week. Given that two thirds of all workplaces globally are informal ones, and a good number of them in home-based industries or as domestic workers in households, both difficult to access from the outside, any effective regulation of the length of the working week will be an enormous challenge and only be feasible if the urge of planners is accompanied by mass mobilisation which is effectively making sure that measures are implemented ${ }^{1}$.

For sure, many of these demands and ideas have been launched before by various organisations and initiatives. The new thing would be for organisations of the global labour movement to launch these as a united program with intersecting elements, in order to provide a reference point for social movements around the globe. For this to take effect, the program has to be sufficiently polemic, aggressive and catchy in order to grab the attention required (nobody will be interested in a considered and balanced proposal that does justice to everyone). The important and crucial issue

1. A shorter working week has also been debated as a way to reduce emissions. If all other indicators remain like today, limiting warming of the planet to 2 degree Celcius would require a 12 hour work week in Sweden, and a 5 hour work week in Germany (Frey, 2019, p. 6). This demonstrates that time reduction alone will not be sufficient to reduce emissions, and thus shifts of jobs to different sectors and changes in resource use are necessary - we will address these issues in the next section. 
is that common demands are raised across continents. These can build on demands already developed, and on the various debates about industrial policy on the one hand, and on global social rights on the other hand.

To sum up, a first common demand can consist in mandatory amounts of spending for health and care, education and public transport as part of national budgets ${ }^{2}$. A second demand focuses on the nationalization of banks, while a third demand sports the 30 hour week as a norm to be accomplished in order to share workplaces and avoid unemployment. No other movements or organisations or sections of society has the authority to voice these demands than actors from the labour movement like global unions federations, and international associations of informal workers, domestic workers, street sellers and slum dwellers.

\section{Planning and the climate crisis}

The global environmental movement is the most important and relevant social movement today, due to the universal significance of ecological collapse, despite the very specific and different effects it has on different groups and populations. "There is no question of waiting for 'the conditions to be ripe'. It is necessary to provoke convergence between social and ecological struggles and fight the most destructive initiatives by powers in the service of capital" (Löwy, 2020, p. 200). Given this enormous challenge, the labour movement has been at best an oscillating and ambivalent partner of the environmental movement. Especially public sector unions and unions from the transport sector are at the forefront of engagement for ecological politics, often under the label of a just transition, but the same cannot be said about many unions from industrial sectors such as the chemical industry and the metal industry, to a large extent with strongholds in automobile, petrochemical and defense companies. An engagement of the labour movement in favour of global planning in order to work against ecological collapse can establish the labour movement as a reliable partner of the environmental movement. The environmental movement needs a more organised form of mass support that only the labour movement can provide today.

Planning with the aim to contain the climate crisis would have to determine in which areas there would be a reduction in emissions and how this will be implemented, coming with a phasing out of brown industries and growth of green industries

2. Some countries, like Brazil, already have such regulation, stipulating fixed percentual amounts of the budgets of federal states and communal districts that go to health and education. In Brazil the underlying problem, apart from a spending cap introduced in 2017, is rather the tax base, since agrobusiness pays lower taxes and the tax system is extremely regressive. 
(Guarini \& Oreiro, 2021). For example, there would be more production of vehicles for public transport and equipment for renewable energy, and less production of automobiles and less coal mining and meat production. In general, a significant amount of conversion from manufacturing to care and personal services would be necessary, and therefore also a transfer of labour power from one sector to the other.

Nonetheless, it is important to highlight that these are processes which would set limits to the interests of some sections of workers to stay in their existing job. Also in a socialist society such a process of conversion would lead to conflicts. This is because employees in sectors that will be reduced will want to keep their jobs - for example, because their workplace is close to home, because they established social networks and friendships at the workplace or due to qualifications that have been acquired over many years. Thus, there is a contradiction between the immediate interests of the workers of some sectors and the transition to an ecologically sustainable society. It would be up to the organisations of the labour movement to underline the priority of conversion over sectorally specific interests of the working class.

Apart from conversion of some industries and the disruption of existing pathways of production and consumption (Eder \& Schneider, 2018), changes in the structure of cities, housing and settlement policies would be a further element of global economic planning: Shorter distances from home to work contribute to diminish $\mathrm{CO}_{2}$ emissions and overall energy use. Especially in developed countries, commuting times and distances increased immensely in the past 20 years, a development which is partly fuelled by rising real estate prices in urban centres, and partly by corporate restructuring which often comes with moving workplaces to more distant locations. Those more far reaching changes will benefit workers since time spent commuting can be used in a different way, and less production and use of fuel will be necessary.

At present, investment in renewable energies would only be one sector in which the state has to intervene in order to contain climate change. Although solar energy has become much cheaper due to Chinese mass production of its installments (Stacey, 2018), there is a global increase in the investment into coal plants (and the bulk of those investments are in China, too), while investment in renewables stagnates since 2015 (Raval, 2020). In other words, there is a lack of state-led policies, means and incentives to invest massively into wind and solar power.

Apart from specific workplaces and the forms of energy provision, consumption would be affected by controversial decisions to combat climate change if planning would be introduced in a serious manner. For example, many emissions can be avoided if less products are transported from far away places. 60 per cent of the industrial production of East Asia goes to Europe and North America. A reduction of freight transport would not only include decisions which products should be imported to 
a lesser extent to the centers of global consumption, i.e. imperialist core countries, in order to save on transport emissions. There are also products that only grow in certain climatic zones, like banana, mango, tobacco products, and chocolate and coffee. Apart from choices to reduce long distance transport of those items, it would also mean that demand for garments, consumer electronics or food produced for export in countries with low wages would drop drastically if imperialist core countries increase reshoring. In this case, reshoring to core countries would save on emissions for shipping and other forms of transport, but would increase unemployment and poverty in those countries that used to a significant extent produce for the Global North. It is therefore of paramount importance to increase regional economic networks that enable a self-sufficient economic development within world regions, a veritable mega challenge that cannot be tackled without any global coordination of economic planning. Any effort to reduce emissions for the transport of consumer products will face the question of imperialism, dependency and the unequal distribution of wealth. Any sudden move away from global trade networks would lead to an increase in poverty and inequality if no counter measures are taken.

Another aspect is that one third of global shipping volume is for oil and other fuels (UNCTAD, 2019, p. 7), thus changes to the fossil basis of heating, energy generations and transport would bring down transport emissions to a larger extent than changes in individual household consumption. This also confirms a look at the origin of $\mathrm{CO}_{2}$ emissions, reinforcing the necessity of structural changes in energy generation and transport systems. The biggest amounts of $\mathrm{CO}_{2}$ emissions originate with the generation of heat and energy (13600 million tons), in manufacturing and construction (6200 million tons) and in transport (8000 million tons, of which 6000 come from road transport, see IEA, 2019). The generation of energy and heat shows the biggest potential for emissions reduction with about a third of the total, and here coal has the biggest share, followed by oil. Greenhouse gas (GHG) emissions stemming from the generation of energy have been reduced about 30 per cent in the EU between 1990 and 2018, and remained stable in the Us, while it saw a 50 per cent increase in Australia, Canada and Japan, a 400 per cent increase in China, and a 500 per cent increase in South Korea (OECD, 2018). GHG due to transport are the second highest amount, and they saw a 20 per cent increase in the US and the EU 28 between 1990 and 2018 and a 450 per cent increase in China. Transport is the only category that continues to see increases across all countries, with few exceptions like the UK and Germany which stabilised transport-related emissions across this period.

On an international scale, the energy related $\mathrm{CO}_{2}$ emissions in the so-called "advanced economies", the terminology used by the International Energy Agency (IEA), are around the same amount as they had been in 1990. But in the "rest" of 
the world (again IEA terminology), emissions doubled since 1990. The wealthier economies have moved part of their production into this "rest", and with it the emissions related to it. For this reason, it is hard to establish who is actually responsible for this increase in emissions.

It would certainly be desirable to establish an equal per capita use of $\mathrm{CO}_{2}$ across countries, since it is still radically unequal between countries along the North-South axis, but also within societies. Unfortunately, such a radical redistribution of wealth and resources will not be realised in time in order to avoid a climate catastrophe. Therefore, the priority would be once again to avoid ecological collapse, at the cost of maintaining some of the existing stark inequalities between and within countries and continents. The specific role of the labour movement in sporting such an agenda would be to install the social dimension into every concrete measure taken to reduce $\mathrm{CO}_{2}$ emissions, pollution and deforestation and to create alternative employment and alternative economic networks that replace unsustainable ones. Changes towards a post-fossil economy is coming anyway with large energy companies like BP, Shell, Equinor and Total investing massively in research on hydrogen and other alternative energy sources (Butler, 2020). Only a proactive intervention of actors from the labour movement together with its allies towards Ecological Structural Change (Guarini \& Oreiro, 2021) can provide the opportunity to ensure that the post-fossil world will be ecologically sustainable and socially just. The current trend is going to a post-fossil world with less $\mathrm{CO}_{2}$ emissions but tremendous pollution in other areas, especially for the mining of rare earths which are needed for some of the alternative technologies (Singh, 2020), e.g. for electric mobility, and with much less jobs and income available for the global working class - in other words, with poverty and famine. For example, the introduction of post-fossil technologies is sparking a new minerals boom, since lithium, cobalt and copper are needed for the new technologies. Mining for post-fossil technologies will continue to emit greenhouse gases, increase the expulsion of populations from their territories, and severely affect communities in mining areas - and the often dangerous and unhealthy work of mining should also be a concern for the labour movement (War on Want, 2021). Only a strong intervention by actors of the labour movement can introduce the necessary elements of global planning to address the interdependencies of a transition to a post-fossil world and its social and economic impact on the majority of the global population.

\section{Problems and challenges for economic planning}

We have already mentioned some of the contradictions between ecological planning and the workplace and consumption interests of workers in the second section. 
Global planning in a socialist perspective comes with a whole bunch of extremely challenging contradictions, and it is better to address those right away than to suggest that global economic planning is just a simple plan that has to be followed once set up.

I will focus on three problems in this section:

- Other than current capitalist planning which has a main aim, to enable the continuation of profit making, socialist planning is aiming towards several aims which can stand in conflict with one another, for example ecological effects of economic actions, wellbeing of workers at the workplace, and expenditure of resources for human welfare in general. Thus, progressive planning has to establish a hierarchy of needs in society, and structure plans accordingly. These are decisions that might affect different parts of the population in a different way, which is prone to lead to conflicts about priorities.

- The second difficult issue is the question of who takes decisions in the end, if there are coordinations of trade unions and social movements on the one hand, and national governments on the other hand. Any centralised institution of planning will hold so much power that it will provide incentives for the abuse of that power. On the other hand, in the absence of market discipline there will be the need for another form of discipline that guarantees that both social and ecological targets of planning are in fact implemented.

- The third issue is the speed and effectivity of decisions which will stand in conflict with a participatory debate on the goals to be implemented by planning. Both poverty and social inequality are urgent needs to be addressed, and the ecological crisis comes with even more urgency. But democracy and popular participation require time.

I will address the three issues one after one, and will draw in part on the writings of German socialist Otto Neurath, who is at times credited to have been at the origin of the socialist calculation debate in the 1920s, and on the works of contemporary scholars who debate the ideas of Neurath in the light of ecological economics (Martinez-Alier, 1995; O’ Neill, 2002; Uebel, 2005).

The first issue concerns the challenge to address multiple aims at the same time, and weigh them against each other. The fact that those aims are incommensurable was one of the central arguments of Neurath against the critique of his writings by Ludwig von Mises who claimed that economic decisions would have to be based on market prices in order to be rational (1935, p. 104). Neurath had analysed the war economies during World War I which allowed national states to organise production targets with a high efficiency. Another reference point for Neurath were public sec- 
tor institutions like schools and hospitals which at this time were mostly organised according to some government estimation of needs for education and health, and not based on market imperatives and price signals.

For even in the past one has not started from units of teaching or sickness in order to decide whether new schools or hospitals should be built; rather one directly set over against one another, even if only at general outlines, the totality of changes caused by schools and those caused by hospitals $(1919 / 1973,145 f)$.

Health and education are in this sense incommensurable concerns that can not be rationally weighed against each other, and in later writings Neurath introduces the limits of natural resources, and the health of coming generations as other such incommensurable issues.

The question may arise, should one protect coal mines or put greater strain on men? The answer depends for example on whether one thinks that hydraulic power may be sufficiently developed or that solar heat might come to be better used etc. If one believes the latter, one may "spend" coal more freely and will hardly waste human effort where coal can be used ${ }^{3}$ (Neurath, 1928/1973, 263).

Thus, Neurath asks why, if the public sector, which also includes the police, military, courts and prisons, and various administrations, is able to organise these institutions with differing, but in some way complementary targets, why should society at large not be able to organise production and services in the same way? Joan Martinez-Alier builds on Neurath's ideas on incommensurability and develops them further: "Incommensurability means that there is no common unit of measurement, but it does not mean that we cannot compare alternative decisions on a rational basis, on different scales of value, as in multi-criteria evaluation" (1995,74f).

It is a commonplace that budget debates on how much should be spent on health, social welfare, defence etc. are one of the centres of parliamentary strife, and the fact that budgets are debated in parliament is generally seen as one of the core characteristics of democracy. Similar debates and decisions can in fact be held and taken about the frameworks of national economies, as we can see with the current plans to phase out coal and fossil fuel based transportation. Thus, it is not impos-

3. It was with reference to this line of argument that Neurath rejected the widespread idea in socialist economics at the time to use the number of labour hours spent as a common unit of measurement: "How could a quantity of electricity which a river provides us with be entered as an increase in amounts of labour units? Or the increase in wind power used in the running wind mills?" (Neurath, 1925/2004b, 468). 
sible to plan economies with various and potentially conflicting targets in mind. For progressive planning today, issues of ecological sustainability and of conditions of work and welfare will have to be balanced. In general, the ecological concerns will have to be prioritised, but minimal conditions in the dimension of welfare and work will have to be guaranteed. In this way, profit-making would be removed from the centre of economic targets set by governments, and replaced by various alternative targets, without removing profit-making from society overall.

The second issue of who takes decisions based on which inputs and how to guarantee discipline and the implementation of targets is much harder to resolve, and probably the most difficult one. The difficulty to replace market discipline with an alternative incentive was at the center of the failure of the Soviet model (Filtzer, 1986; Clegg \& Lucas, 2020, p. 98; Bernes, 2020, p. 58). Workers had a right to work and acquired a significant amount of control of workplaces, and basic welfare was organised on a society wide level. But the lack of clear incentives in the centrally planned economy resulted in a lack of resources for production, leading factories to stockpile and to a low quality of goods produced. Traditional systems of socialist planning in the Soviet bloc estimated average values of consumption that led to production targets for companies, origin of the infamous "ideology of tons", and often leading to production of goods that were not needed ${ }^{4}$. At the same time, the extremely centralised planning procedures and opaque party structures demotivated citizens and workers to participate in social and political decision-making.

A model of global economic planning guided by the environmental and the labour movement will have to address both the issues of power and participation on the one hand, and of discipline and effectivity of implementation of planning targets on the other hand: How to avoid an over-centralisation of planning, and guarantee popular participation in the planning process? While there have to be checks and balances in order to avoid a dictatorship of the planners, decentralisation and lack of a clear decision making-structure come with the risk that the targets of ecological sustainability and the welfare of populations, including decent conditions of work, will be flouted.

Market solutions are effective in imposing discipline, but until now lack effectivity in combating climate change. While many production processes have increased their resource use immensely, the total amount of $\mathrm{CO}_{2}$ emissions keeps rising due to a multiplication of those production processes (OECD, 2018). The same holds for 
the use of automobiles, whose emissions per kilometre have been reduced drastically, but with more automobiles in use on longer distances, the total emissions due to road transport are increasing, too (OECD, 2018). It is exactly this mismatch between resource-saving optimisation of specific processes and the overall increase of emissions which requires global planning, with a focus on switching to technologies that enable a long term reduction of emissions and pollution, and an overall reduction in resource use. If the right incentives are set by governments, then a transition to post-fossil economies is possible within a system which is still largely dominated by capitalist enterprises. Without coordination beyond market mechanisms this transition will occur only in a half-hearted manner and not with the speed that is required in order to avoid major ecological disasters and the social and political consequences that will accompany them.

Schemes that penalise or subsidise the use of certain technologies and production goods in terms of their resource use and polluting effects already exist and can be used on a wider scale. For example, the replacement of the use of aluminium in as many processes as possible due to the enormous energy use of the aluminium industry would be one starting point. This industry would not be profitable at all if governments around the world would not provide subsidised energy to it, in other words those governments set the wrong incentives after all.

Neurath did not really work on the question of discipline and incentives. An effective control of the action of planners would surely require an elaborate system of checks that again can be held accountable. At this point it is sufficient to mention that Neurath's scheme of economic planning involved the cooperation between four different centres with different responsibilities which are a) to design different, alternative plans, b) to apply the chosen plan to economic sectors, c) to control efficient application of plans, and d) to control the results of the directives of the plan (Uebel, 2005, p. 333).

As to the methods of planning as such, it is not required that there is a central institution of global planning. Given the continuing relevance of national states, national governments would remain the addressees of the changes. But the crucial question is how a programme for global planning would be coordinated and decided upon, so that there is a common agenda across various countries. The methods of coordination could be similar to the ones used for Global Social Forums and other similar meetings which managed to agree on common agendas. On the national level, unions and social movement organisations can adapt the global agenda to specific circumstances. The important issue would consist in a global adherence to the same agenda, and a feedback on specific regional and national experiences made with the agenda itself and also with the difficulties met in implementing the demands. 
This is the point where we come to the third issue: the contradiction between speed and democracy. The ecological crisis, but also poverty, unemployment and health are issues that can hardly wait, and in some cases there will not be much deliberation, but social, political and economic pressure that will speed up some decisions. Probably regarding issues redistribution of resources to the poor majority of the global population advances will only be made due the threat of ungovernability if demands are not met. The Covid-19 crisis accelerates all dimensions of inequality, and it is in this case that we have to bet on the existing and coming contradictions to generate the pressure for sweeping changes. The most likely scenario today is a transition to post fossil economies that leads to increasing inequality and poverty, and such a development can only be avoided with proactive planning by the labour and ecological movements.

\section{Conclusions}

For the labour movement, a post-Covid-19 and post climate change approach to global planning is a unique chance to renew its political stake. In this period of escalating and overlapping crises, there a few actors able to fill up the ideological vaccuum left over by failing neoliberalism. The environmental movement alone is not strong enough to initiate a change in the relationship of social forces which will be necessary to confront both the social and environmental crisis. Only a strong alliance between environmental and labour causes can stem the gigantic challenge to move the ideological barriers away to rely on solutions which are not market-based. Obviously, such calls have been made in the past, but a serious debate about global planning and the most urgent and first necessary steps toward it can unite the efforts necessary for a socio-ecological transition. Such a debate will be a process and the important trigger of such a debate would be to provide a direction and demonstrate that progressive movements are taking the initiative and do not wait for the next catastrophe to occur which can then only be a confronted in a responsive hap-hazard manner. In contrast to this, it is necessary to establish a distinct and specific plan with a long-term perspective.

In this respect, it is important to underline that global economic planning is already something that is executed by various multinational companies. At the same time, one should make clear that economic planning is neither identical with capitalist planning, nor with Soviet planning, which it is most often associated, but also not with the mostly authoritarian experiences with planning in developmental states. Planning includes to set priorities, but those priorities can be set in a democratic process of decision making, and be informed by trade unions and social movements. 
Of course, none of those actors is innocent, and there are plenty of diverging interests between those actors which would have to be resolved.

At this point in time, the ideological shift towards the idea that global economic planning from below is first of all of urgent necessity, and, second, a realistic possibility, is the crucial barrier to be taken. No other agents than the global environmental and labour movements do have the adherence, competence, authority and power to exercise such a program designed to manage a social-ecological transition. National governments and political parties can be partners in this project, but without pressure from social movements these actors to easily give in to the interests of the capitalist class on which they are highly dependent. Several factions of corporate elites can also be partners in this endeavour but there will be certain corporate groups, like agribusiness and mining companies, whose stiff resistance will have to be overcome which will not be an easy process.

This moment of a profound global crisis is a moment in which ideological changes can be the key to enact overall change. Debates about a green new deal, green industrial policy, just transition, ecosocialism, cosmovision, pluriverse and ecological macroeconomics, to name just a few, are quite advanced and present all the solutions needed. What is lacking today is a blunt proposal to put those in practice, and the unanimous support by the most powerful social movements, the labour and the environmental movement, which are in themselves very diversified and plural actors.

\section{References}

Allen, R. C. (2003), From farm to factory: A reinterpretation of the Soviet industrial revolution. Princeton, Princeton University Press.

Belcher, Oliver; Bigger, Patrick; Neimark, Ben \& Kennelly, Cara (2020), "Hidden carbon costs of the 'everywhere war': Logistics, geopolitical ecology, and the carbon-boot print of the Us military". Transactions of the Institute of British Geographers, 45 (1): 65-80.

Bell, David N. F. \& Blanchflower, David G. (28 April 2020), "Us and uk Labour markets before and during the Covid-19 Crash". National Institute Economic Review, 252.

Butler, Nick. (15 July 2020), "How oil majors bought into green energy”. Financial Times.

Cook, Maria Lorena; DutTa, Madhumita; Gallas, Alexander; Nowak, Jörg \& Scully, Ben. (2020). "Global labour studies in the pandemic: Notes for an emerging agenda”. Global Labour Journal, 11 (2): 74-88. 
Dupuy, Alex \& YrChiK, John. (1978), “Socialist planning and social transformation in Cuba: A contribution to the debate". Review of Radical Political Economics, 10 (4): 48-60. https:// doi.org/10.1177/048661347801000404.

Eder, Julia \& Schneider, Etienne. (2018), "Progressive industrial policy - A remedy for Europe!?”. Journal für Entwicklungspolitik, 34 (3/4): 108-142.

FILTZER, Donald. (1986), Soviet workers and Stalinist industrialization: The formation of modern Soviet production relations, 1928-1941. Londres, Dover, NH, Pluto Press.

FreY, Philipp. (2019), "The ecological limits of work: On carbon emissions, carbon budgets and working time". http://autonomy.work/wp-content/uploads/2019/05/The-Ecological-Limits-of-Work-final.pdf.

Gehrke, Bernd. (May 192020), “Gegen den Markt, aber für den Plan? Ökosozialistische Antworten auf die Klimakrise brauchen eine Reflexion der Geschichte von Planwirtschaften”. Analyse und Kritik, 660. https://www.akweb.de/ak_s/ak660/index.htm.

GuARINI, Giulio \& Oreiro, José Luis. (2021), "An ecological view of new developmentalism: A proposal of integration”, preprint. DOI: 10.13140/RG.2.2.10065.66408.

Hudson, Michael. (21 February 2021), “'Changes in super imperialism', interview led by Oscar Brisset". Janata Weekly, https://janataweekly.org/michael-hudson-changes-in-super-imperialism/.

ILO. (25 January 2021), “Covid-19 and the world of work”. Seventh edition. https://www.ilo.org/ wcmsp5/groups/public/---dgreports/---dcomm/documents/briefingnote/wcms_767028. pdf.

Iea, International Energy Agency. (2019), “ $\mathrm{CO}_{2}$ emissions from fuel combustion”. Highlights.

Löwy, Michael. (24 nov. 2020), "Xv Theses on the ecological crisis and the pandemia”. Crisis \& Critique, 7 (3): 197-200. https://crisiscritique.org/uploads/24-11-2020/michael-lowy.pdf?v=1.

IPCC, Intergovernmental Panel on Climate Change. (2018), Global warming of 1.5 C. Special Report. https://www.ipcc.ch/sr15/.

Mazzucato, Mariana. (2018), The entrepreneurial state. Debunking public vs. private sector myths. Londres, Penguin.

Martinez-Alier, Joan. (1995), "Political ecology, distributional conflicts, and economic incommensurability". New Left Review, 21: 70-87.

Martinez-Alier, Joan; Munda, Giuseppe \& O’ Neill, John. (1998), “Weak comparability of values as a foundation for ecological economics". Ecological Economics, 26: 277-286.

Marx, Karl. (1992), Capital, Vol. 1, A critique of political economy. Nova York, Penguin Classics. Mises, Ludwig von. (1935), "Economic calculation in the socialist commonwealth". In: HAYEK, Friedrich August von (ed.). Collectivist economic planning. Londres, Routledge, pp. 87-130.

Mryamura, Satoshi. (10 March 2021), “Turbulence ahead: labour and struggles in times of the Covid-19 pandemic in India”. Canadian Journal of Development Studies / Revue Cana- 
dienne d'Études du Développement, https://www.tandfonline.com/doi/abs/10.1080/022 55189.2021 .1894415$.

Neurath, Otto. (1919/1973), "Character and way of socialisation”. In: Neurath, Otto. Empiricism and sociology. Edited by M. Neurath and R. S. Cohen. Dordrecht, Reidel, pp. 135-150.

Neurath, Otto. (1928/1973), "Personal life and class struggle". In: Neurath, Otto. Empiricism and sociology. Dordrecht, Reidel, pp. 249-298.

Neurath, Otto. (1925/2004), “Total socialization”. In: Neurath, Otto. Economic writings: Selections, 1904-1945. Edited by T. E. Uebel and R. S. Cohen. Dordrecht, Kluwer, pp. 371-404.

OECD. (2018), "National inventory submissions 2018 to the United Nations Framework Convention on Climate Change (UNFCCC, CRF tables), and replies to the OECD State of the environment questionnaire”. https://stats.oecd.org/Index.aspx?DataSetCode=AIR_GHG.

O’NeILl, John. (2002), “Socialist calculation and environmental valuation: money, markets, and ecology”. Science \& Society, 66: 137-151.

Raval, Anjili. (27 May 2020), "Global energy spending to fall $\$ 400 b n$ due to Coronavirus crisis". Financial Times.

Ritchie, Hannah \& Roser, Max. (first version May 2017, revised December 2019), " $\mathrm{CO}_{2}$ and greenhouse gas emissions". Our World in Data, ourworldindata.org.

Roberts, Michael. (2021), “Biden's four years”. The Next Recession (blog), January 20.

https://thenextrecession.wordpress.com/2021/01/20/bidens-four-years/.

Roca, Sergio G. (1986), "State enterprises in Cuba under the new System of Planning and Management (SDPE)”. Cuban Studies, 16: 153-179. https://www.jstor.org/stable/24485981.

RODRIK, Dani. (2004). "Industrial policy for the twenty-first century”. Unido. https://drodrik. scholar.harvard.edu/publications/industrial-policy-twenty-first-century.

Singh, Nem. (March 5, 2021), "Rare earths and the new battleground for geo-economic supremacy". https://nemsingh.com/2021/03/05/rare-earths-and-the-new-battleground-for-geo-economic-supremacy/.

Singhi, Shruti \& Tagat, Anirudh. (2020), "Lawless: A policy perspective on labour laws and migrant workers displaced by Covid-19”. Available at SSRN: https://papers.ssrn.com/sol3/ papers.cfm?abstract_id=3756097.

Shaxson, Nicholas. (2011), Treasure islands: Tax havens and the men who stole the world. Londres, Palgrave Macmillan

STACEY, Kiran. (September 5, 2018), "China and India lead the surge to solar energy”. Financial Times.

Uebel, Thomas E. (2005), "Incommensurability, ecology and planning: Neurath in the socialist calculation debate, 1919-1928". History of Political Economy, 37 (2): 309-342.

UnCTad/United Nations Conference on Trade and Development. (2019), Review of Mariti- 
me Transport 2019, Nova York/Genf, unter: https://unctad.org/en/PublicationsLibrary/ rmt2019_en.pdf.

WAR ON WANT. (21 March 2021), “A material transition”. https://waronwant.org/sites/default/ files/2021-03/A\%20Material\%20Transition_report_War\%20on\%20Want.pdf.

Zimbalist, Andrew. (1987), “Analyzing Cuban planning: A response to Roca”. Cuban Studies, 17: 159-165. https://www.jstor.org/stable/24486061.

\section{Abstract}

Global Economic Planning as a Challenge for the Labour Movement

The central line of argument in this contribution is that the urgency of the economic, social and environmental crises demands to go beyond the institutionalist efforts to install more Global Framework Agreements or Decent Work Campaigns that often only come with piecemeal changes, if at all. The social uprisings in various countries around the globe that erupted in 2019 and 2020 underline the emerging pressure towards a broader vision of systemic change. The shift of emphasis towards Global Economic Planning opens up the following perspectives: 1. It allows to study and adapt the methods used by transnational corporations in economic planning for alternative purposes. 2. It allows to retrieve experiences made both in capitalist planning, i.e. in the framework of industrial policy and developmental states, and in socialist planning and to apply enhanced versions of both. 3. It allows to intervene strategically in order to exploit the potentials of renewable energy for which investment is stagnating globally. 4. It offers an avenue for the labour movement to become a reliable partner of environmental initiatives and the global climate movement. 5. It can provide an avenue for mass participation in systemic change with concrete objectives like the conversion of the automobile industry, decentralised renewable energy grids, and public and community based health and care systems.

Keywords: Planning; Socialism; Climate change; Imperialism; Energy.

\section{Resumo}

Planejamento econômico global como um desafio para o movimento dos trabalhadores

A linha central do argumento nesta contribuição é que a urgência das crises econômica, social e ambiental exige ir além dos esforços institucionalistas para instalar mais Acordos Marco-Globais ou Campanhas de Trabalho Digno. As revoltas sociais em vários países do globo que eclodiram em 2019 e 2020 sublinham a pressão emergente no sentido de uma visão mais ampla da mudança sistêmica. A mudança de ênfase para o Planejamento Econômico Global abre as seguintes perspectivas: 1) Permite estudar e adaptar os métodos utilizados pelas empresas transnacionais no planejamento econômico para fins alternativos. 2) Possibilita recuperar experiências feitas tanto no planejamento capitalista, ou seja, no quadro da política industrial e dos estados de 
desenvolvimento, como no planejamento socialista, e aplicar versões melhoradas de ambos. 3) Permite intervir estrategicamente a fim de explorar as potencialidades das energias renováveis para as quais o investimento está a estagnar globalmente desde 2015. 4) Oferece uma via para que o movimento laboral se torne um parceiro fiável das iniciativas ambientais e do movimento climático global. 5) Pode proporcionar uma via para a participação em massa na mudança sistêmica com objetivos concretos, como a conversão da indústria automóvel, redes descentralizadas de energias renováveis, um sistema de saúde público e comunitário, entre outros.

Palavras-chave: Planejamento; Socialismo; Mudança climática; Imperialismo; Energia.

Texto recebido em 5/4/2021 e aprovado em 19/4/2021.

DOI: 10.11606/0103-2070.ts.2021.183791.

JöRG NOWAK is a visiting professor at Universidade de Brasilia, Brazil. He works on strikes and social movements, the political economy of logistics and infrastructure, and Althusserian Marxism. Last book publication: Mass Strikes and Social Movements in Brazil and India. Popular Mobilisation in the Long Depression, Palgrave (2019).E-mail: joerg.nowak@gmx.de. 